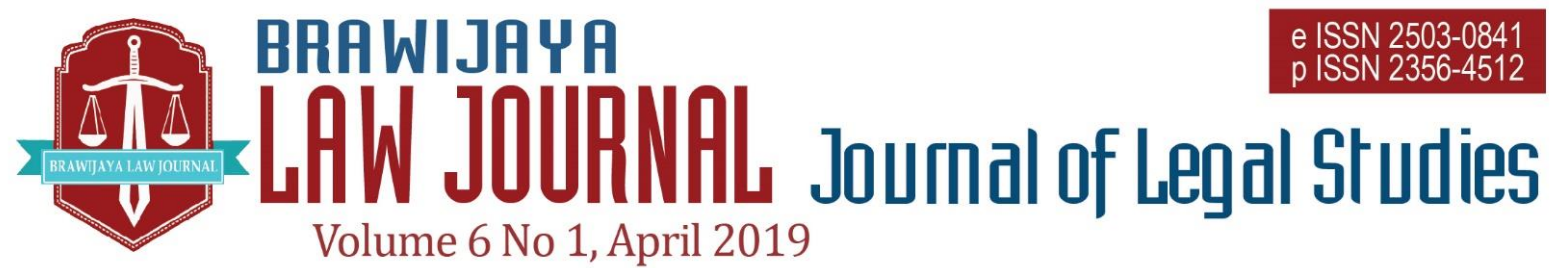

Nationally Accredited No. 30/E/KPT/2018 Dated 24th October 2018

This work is licensed under a Creative Commons Attribution-NonCommercial 4.0 International License

\title{
Legal Protection for Investee Company in Venture Capital Agreement in Indonesia
}

\author{
Sihabudin $^{a}$ \\ ${ }^{a}$ Faculty of Law, Brawijaya University \\ Email : sihabudin.fhub@gmail.com
}

Submitted : 2018-11-18 | Accepted : 2019-02-08

\begin{abstract}
Business and entrepreneurship are one of the fundamental and important factors in the economy of a nation. In Indonesia lending is being intensified to small and medium-sized companies that are unable to borrow capital from banks through the establishment of venture capital by the government. The existence and role of financial institutions in the form of venture capital in Indonesia is important to study, because it is a new institution that is starting to develop, which certainly has an influence on the development of the business world and legal institutions and institutions. The research method used is empirical juridical, which is qualitative by means of descriptive analysis. The results of the study are that although venture capital has not been based on clear legal aspects, in practice, venture capital activities are complemented by an agreement. Venture Capitalist has a stronger position on the investee company, while freedom of contract can only be applied well when both parties have the same position. However, venture capital tends to protect interest (capital) with special provisions, including its responsibilities. Therefore there is a need for a model and further regulation of the contents of the "standard venture capital agreement", especially the financing mechanism as well as its implementation instructions, so as to provide clearer, more complete and stronger implementation guidelines. A financing agreement made between a venture capital company and its partner company is based on a standard contract that requires supervision and protection to maintain balance. Measures of protection and supervision are through the basis of legislation, control carried out by the government, control carried out by judges (courts) and legal consultants and notaries.
\end{abstract}

Keywords: economy; venture capital; legal protection; investee company; agreement; partnership.

\section{INTRODUCTION}

Entrepreneurship and business world consist of various levels, namely small, medium and large companies. The small business sector has an important role to play in addressing development challenges, namely employment expansion, more equitable income generation, and increase 
export. ${ }^{1}$ Therefore, there is a need to maintain a more serious commitment and greater effort to improve small business sector, because efforts to develop small business sector is an integral part of the overall process of economic development of Indonesia as a country. One of the obstacles faced by small and medium entrepreneurs is funding/capital as a means to pioneer, maintain, and run their business and develop it. ${ }^{2}$ Therefore, there is an alternative to overcome the difficulties faced by entrepreneurs to get the funds. The alternative to be discussed in this paper is the implementation of venture capital for small and medium enterprises, which has the potential to develop well.

The existence and role of financing institutions in the form of venture capital in Indonesia is important to be studied, because it is a new institution that began to develop, which certainly has an influence on the development of business, the companies, and the legal institutions. Unfortunately this institution is not accompanied by the establishment of a legal order governing the operation of legal relationships between venture capital firms and financed companies.

Based on this background, it will be examined whether the legal protection of the business partner in the cooperation agreement is guaranteed so that the national economy is truly lifted and a sense of justice is created and whether the standard contract model implemented as a venture capital financing agreement meets justice for both parties and does not cause any other legal inequality?

\section{LEGAL MATERIALS AND METHODS}

This research uses qualitative juridical empirical method with descriptive analysis method through literature and field. ${ }^{3}$

This research is also a legal literature research. The study was carried out mainly on legal materials in the form of laws and agreements, literature books, scientific papers written by experts, research results and reports, magazines, newspapers and other writings. Furthermore, field research was conducted in the form of interviews and observations to determine the implementation of the activities of venture capital financing institutions in the community as well as their role, particularly the legal relationship between venture capitalists and their partner companies (investee company).

As a starting point will be used literature study in the field of law and in the economic field concerning the emergence and development of venture capital in Indonesia and abroad, so that can be drawn conclusions about what things are still needed for the development of venture capital in Indonesia.

Further Soerjono (1988) ${ }^{4}$ states that "this study is a study to look for regulatory provisions" governing venture capital issues. This is relevant to Bungin's in Laely (2007) ${ }^{5}$ statement that "research can be supported by

\footnotetext{
Badrul Zaman dan Mariam D., Hukum Jaminan dan Jaminan Kredit Perbankan di Indonesia (Jakarta, Raja Grafindo Persada, 2007) 43.

2 Kenneth J. \& Narongchai A., Small and Medium Business Improvement in the Asia. (Aspek-aspek Finansial Usaha Kecil dan Menengah: Studi Kasus Asean). penerjemah Yadrifil, (Jakarta: LP3ES, 1992) 8.
}

3 Surjono Sukanto, Penelitian Hukum Normatif, (Jakarta, Adika Cipta, 1988) 40.

4 Zaeni Asyhadie, Hukum Bisnis Prinsip dan Pelaksanaannya di Indonesia, (Jakarta, PT Raja Grafindo Persada. 2012) 42.

5 Bungin in Laely, Dimensi Metodologis: Dalam Penelitian Sosial, (Surabaya, Usaha Nasional, 2007) 348. 
looking at the circumstances in practice and analyzing them".

The results of this study are certainly expected to determine the better policy to formulate its development rules.

\section{RESULT AND DISCUSSION}

\section{Venture Capital and the Basic Legal Aspects}

The word venture is generally related to risk management which is often referred to as calculated risk. Venture businesses have a very broad scope, which includes formal business ripples or that have not been formalized in accordance with the scope of local law or that have not been reached by local formal law. ${ }^{6}$

The venture capital financing model does not have legal instruments that can minimize risk, even to bear the risk of business failure. Even if the business partner company at a certain time earns a profit, then it is not certain that the profit / profit can directly become dividends which are directly shared with the shareholders.

By conception, there are 4 (four) possible packages of venture capital, which are included in the business partner of the company, namely: ${ }^{7}$

1) Capital participation only.

2) Equity participation and seat allocation in the management structure or take part in the management.

3) Equity participation by providing management consulting support.

4) Equity participation accompanied by technology.

6 Thoby Mutis, Fenomena dan Riak Ventura, Usahawan No.9 Th.XXIII September 1994.

7 The Asian Venture Capital Journal, The Guide to Venture Capital in Asia, Hong Kong: The AVCJ., 1990, p. 18.
The venture capital financing system by means of equity participation is a government policy that has certain objectives, namely first, with the existence of venture capital so that there is an opportunity to obtain capital that is evenly distributed among companies in Indonesia. Secondly, with this capital participation system, the government expects that business partner companies that are not small and mediumsized companies will have the opportunity to obtain capital that is not burdensome, in the form of interest and the provision of collaterals as applied to lending in banking institutions. $^{8}$

The legal relationship of capital participation is a cooperative or partnership relationship, which includes "cooperative relations between small businesses and medium-sized businesses with large businesses with regard to the principle of mutual need, mutual reinforcement and mutual benefit". ${ }^{9}$ The partnership is carried out accompanied by coaching and development in one or more of the fields of production and processing, marketing, capital, human resources, and technology. In conducting partnership relations both parties have equal legal standing. ${ }^{10}$

\section{Some Problems with Legal Relations in Venture Capital in Indonesia}

Some venture capital companies that have financed a business partner company, which consists of small and medium-sized companies, state that small companies generally face capital, marketing, business relations, less skilled problems in the

8 Rachmat, Budi, Modal Ventura: Cara Mudah Meningkatkan Usaha Mikro, Kecil dan Menengah, (Bogor, Ghalia Indonesia 2005) 348.

9 Article 1 paragraph (8) Draft Law on Small Business.

10 Article 26 paragraph (4) of Law No. 9 of 1995 concerning Small Business. 
technical and administrative fields. "Most small companies still use traditional technology, so they are often unable to maintain and guarantee the quality of production"11, which results in the difficulty of marketing production and losing competition in the market, so that the development of the business is hampered. This is one of the obstacles to developing a business partner company, which generally consists of small and medium enterprises.

"The obstacle in creating cooperation between venture capital companies and business partner companies is the form of small companies in Indonesia, most of them are family businesses, so that supervision in the corporate environment is less objective than unprofessional. "Small companies in Indonesia often have no strict limits between business interests and family interests. Sometimes the actions of family members are less business like and do not understand the scope of their business. Most small business owners are not willing or unusual to delegate broad rights and obligations to non-family members" The legal relationship constraints of working on a venture capital system can also be caused by both parties having different fundamental interests. Investors, namely Venture Capital, have an interest so that their capital participation is secure, immediately get results and try to get capital gains immediately when divesting or freeing themselves from financing at a business partner company by selling their shares. ${ }^{12}$ While the business partner company or business partner as a capital user generally has its own interests and will object if the space for movement is limited as a result of the intervention of venture capital companies to manage their company and profits are

11 Tulus Tambunan,Usaha Mikro Kecil dan Menengah di Indonesia: Isu-isu Penting. (Jakarta, LP3ES, 2012) 40. distributed because the funds can be used as cheap funds to enlarge investment.

The objection from the business partner or the investee company is reasonable because it does not understand the emergence of the concept of financing a type of venture capital in the form of capital participation, because venture capital financing is considered as an injection of fresh funds, which do have a role in the development of the company. so if profits are immediately divided, then it is felt to reduce the funds whose hopes can be used to develop their business activities, even though the business partner company also realizes that the funds or capital are not the only determinant of the success of the company. So the problem is how to bring together different interests the fundamental, so that the legal relationship of cooperation between venture capitalists, namely venture capital companies and capital users, namely business partner companies can be carried out well and mutually beneficial.

\section{Implementation of Legal Partnership of Funding}

The Implementation of legal partnership of venture capital funding (especially the one performed by Bahana Pembinaan Usaha Indonesia) has two models, namely the form of cooperation by buying shares (equity) to the partner company, and providing loans in the form of credit. The participation of venture capital company is done by injecting equity fund (share) to its business partner, and as a minority shareholder with a maximum of $49 \%$. If it turns out that the $49 \%$ funding from the venture capital is not sufficient, then the venture capital companies usually lend to

12 Rachmat, Budi, Modal Ventura: Cara Mudah Meningkatkan Usaha Mikro, Kecil dan Menengah, (Bogor, Ghalia Indonesia 2005) 78. 
their partner companies under a separate agreement, in the form of a loan.

Business partner company or business cooperative is not necessarily must be a limited liability company, even Presidential Decree of the Republic of Indonesia no. 9 in 2009 and Decree of the Minister of Finance No. 18 in 2012 do not specify the form of business entity of the business partner company.

The venture capital company puts its funds into its business partner company based on the belief that the entrepreneur of the prospective partner will succeed in developing his business. Therefore, the venture capitalist must know more closely who the entrepreneur (investee company), his personality, experience, talent and the important spirit of his company's entrepreneurship. ${ }^{13}$

Legal Partnership of Funding According to Formal Agreement: The occurrence of an agreement to be poured into a financing agreement between a Venture Capital Company (VCC) and its Business Partner Company (BPC) was also started with a concept of agreement from the venture capitalist or investor company, commonly referred to as the Standard Contract. Originally, the standard contract was made in respect of an activity requiring the existence of a mass and collective agreement. "Vera Bolger named the standard contract as a bid which character is' take it or leave it' contract. ${ }^{14}$ If the debtor is aware of any conditions, then the debtor may be just accepting what it is or does not accept it at all, whereas the possibility of making a change is completely absent. Those conditions, that

13 H. Z. Asikin., Hukum Dagang, (Jakarta, Raja Grafindo Persada. 2013) 51.

14 B. A. Garner, Black's Law Dictionary. 8th Edition. (West Publishing CO.St. Paul, Minn, 2004) 212. have been partially determined are often called as exoneration/exemption clause.

These exoneration clauses can appear in various forms. Such clauses may take the form of a complete release from the responsibility that should be borne by its party in the event of a breach of a promise (default). The exoneration clauses may also constitute restrictions on the amount of damages that can be claimed. The clause may also constitute a time limit for the disadvantaged person to be able to file a lawsuit or to seek redress. In this last field, the time limit is often shorter than the time limit set by law.

In the present and in the future, as a result of globalization may be a standard contract with the form of these forms will broadly dominate the business world in Indonesia. Standard contract and exemption/exoneration clauses in Indonesia can be distinguished in 3 (three) main types, namely ${ }^{15}$ :

First, a unilateral standard contract, that is a contract which contents are determined by the stronger party of positions in the agreement. The one referred as the strong party is the creditor who typically has a stronger economic position than the debtor. Both parties are generally bound in an organization, for example on collective labor contract.

Second, the standard contract established by the government that is a standard contract that has the object of land rights. In the field of land (agrarian) there are forms of agreement which is regulated by the Minister of Domestic Affairs Decree No. 104 / Dja / 1977, which among them is in the form of sale and purchase deed model 1156727 ,

15 Zaeni Asyhadie, Hukum Bisnis Prinsip dan Pelaksanaannya di Indonesia, (Jakarta, PT Raja Grafindo Persada. 2012) 42. 
mortgages deed model 1045055, and the others.

Third, the standard contract specified in the notary or advocate environment. In their environment there are agreements whose concept has since been provided to meet the demands of members of the community seeking the assistance of a notary or an advocate concerned. According to the Dutch literature, this type of agreement is called the Contract Model.

\section{Legal Protection for Business Partner Company}

Conceptually, venture capital is a high risk capital, because the financing is not accompanied by the guarantee of goods (collateral) ${ }^{16}$, so there is no guarantee for the interests and security to the capital of venture capital companies. Even the basic concept of financing system is partnership cooperation, where both parties have equal position.

Financing by a venture capital company to a partnering company is made by a cooperative or partnership agreement, pursuant to Article 8 of Law Number 20 in $2008,{ }^{17}$ this partnership relationship of both parties, should have an equal legal standing. Article 8 of this law stipulates that the partnership relationship is set forth in a written agreement that at least regulates the form and scope of the partnership business, the rights and obligations of each party, the form of coaching and development, as well as the duration and settlement of disputes. In the implementation of partnership relationship between small-scaled business and medium-sized enterprises with a large business is prohibited to own and / or control the partner company's small business.

16 Regina Brehny \& Butler Brendan, A Guide to Ventura Capital, 8th Edition, (Irish Venture Capital Association (IVCA), 2015) 311.
The Law no. 20 in 2008 on Small Business can be used as a foundation for legal partnership concerning venture capital. Based on the guarantees regulated by the law on small business, there is actually some legal protection for small business, and for the financing company there is no need to worry about the funds that are attached to the small company, because there is an insurance institution. However, the law on small business, which has given legal certainty, still seems to be underestimating the protection of investors, so it seems that in making the agreement, the investors are still trying to protect their interests through the terms set out in the agreements they made, so that the content of the agreement appears to be an unequal agreement of rights and obligations.

The principal issue of Standard Contract is an exoneration/exemption clause, which often incriminates the debtor. Indonesia does not yet have legislation or jurisprudence, which specifically regulates clauses in standard contract. Law No. 8 in 1999 on Consumer Protection has one article, namely article 18 which regulates the provision of standard clause, but the provision is not yet adequate to regulate standard contract in general. The provisions of standard contract set forth in Law No. 8 in 1999 on Consumer Protection is apparently specifically intended for an agreement made by a company only with the consumers, both consumers of goods and services.

Based on such description, the validity and enforcement of standard contract shall be governed by basic rules as the rules of the game, so that the provisions and clauses of standard contract, either partially or wholly, does not one-sided, so as to maintain a sense

17 Pasal 8(b) Undang-undang No 20 Tahun 2008 about Usaha Mikro, Kecil dan Menengah. 
of justice and / or balance. The protection that must be provided to prevent arbitrariness of strong parties can be done by lawmakers, the government of the Republic of Indonesia, the Court, and Legal Counsels and notary.

On the establishment of legislation on standard contract and the occurrence of agreements in the making of a treaty, it is necessary to pay attention and consider the principles of existing agreements, which include Considering the Principles of Agreement (Consensus), moral values, principles of appropriateness, and the Freedom of Contracting Principle for Indonesia.

Venture capital financing agreements and business transactions in Indonesia that use a lot of standard contract should encourage all of us to give more attention to the basic rules governing standard contract. In addition, to obtain equal rights and obligations between the investors and the recipients of capital requires Improvement on Venture Capital Material Law.

\section{Venture Capital Disputes Settlement}

Funding for equity participation by venture capital sometimes experiences problems in the form of bad capital or a business partner company running away from the responsibility to return capital from a venture capital company. If the return on capital is the obligation of the business partner company to experience congestion, then the handling can be done with several approaches, namely ${ }^{18}$

1) With a postponement of return time, without being burdened with additional margin (the term in banking is called interest).

18 Gradan Mack, 'Fueling the Grouwth of Black Companies' (1994) 25(4) Journal Black

Enterprise, 21
2) Suspension of return times by adding profit margins. This is done by removing the first agreement and renewing it with a new agreement.

By law, these disputes can be resolved through ordinary courts or arbitration (arbitration) courts. If there is a broken promise (wanprestatie) in the implementation of venture capital financing with a profit sharing system, then there are several ways to resolve the problem, namely by deliberation and through the court.

If the settlement is carried out by deliberation, it means the venture capital company with the partner company has an open and family meeting to solve the problem together with negotiations. The steps taken by venture capital companies are:

1) Obtaining past business partner data (post performance) includes finance, marketing, production and management techniques.

2) Analyzing available data both external and internal.

Based on the steps mentioned above, then the capital is entered into the company of the business partner in the following way:

1) Rescue of problem financing for projects that can be managed. The way to save is done: providing rescheduling, giving additional working capital financing, selling assets that are less useful, requiring professional staff in a business partner company.

2) Rescue of troubled financing for projects that cannot be or are difficult to cure. How to save:

a. Through the Court.

b. Under-the-sale of assets, meaning the settlement by selling goods not through the court. 


\section{Specific Legal Principles Required in the} Standard Agreement

There is a view that states that so that the standard agreements that develop in the community, especially in the business world do not cause negative impacts in the sense that there is no injustice, control is needed from certain parties, including the government, but there is a view that these controls will increase the length bureaucracy in the life of the business world and adding to the burden of costs, so the important thing is actually the enactment and enforcement of legal principles that are specific to the standard contract.

For those who view the need for control, it is stated that standard agreements and exoneration / exemption clauses that have no control or supervision from certain institutions or parties may lead to conflict with the principle of consensualism and the principle of freedom of contract that is responsible, especially when viewed from the principles the principle in the Indonesian national legal system, which at the end of every activity of community interest takes precedence. In the standard agreement the position of creditors and debtors is not balanced. The creditor's monopoly position opens a wide opportunity for him to abuse his position, while the practice of standard agreements continues to develop in the lives of the people. The challenge that must be faced is how to provide protection to debtors, whose positions are relatively weak.

At present, the legal relationship of a venture capital company with its business partner including other legal relationships, which uses a standard agreement does not yet have a limit, except the standard clause in the legal relationship of the company with consumers of goods and services contained in the Law on Consumer Protection (Law Number 8 of 1999).
If there are one-sided agreements as a result of not or lack of operation of the principle of freedom of contract and the occurrence of an unbalanced standard agreement, the government must rectify the situation. This can be done by:

1) Lawmakers;

2) Government of the Republic of Indonesia;

3) Courts, and

4) Legal consultants and notaries

The venture capital financing agreement and business transactions in Indonesia that use many standard agreements, should encourage us all to pay greater attention to the basic rules governing the standard agreement.

In the framework of making standard contract law in Indonesia, you can see and consider the basic rules of the existing standard agreement, both regulations in Indonesia and in other countries, which include:

1) Provisions on the inclusion of standard clauses in article 18 of Act Number 8 of 1999 concerning Consumer Protection;

2) Article 6.5.2. and 6.5.1.3. The new Civil Code in the Netherlands.

3) Basic rules set by the courts in the United Kingdom concerning the provisions in the Standard Documents that are not signed.

4) Article 2-302 Uniform Commercial Code 1978, in the United States.

5) Agreement principles, to fulfill a sense of justice. The specific principle of the standard agreement is meant that: if the contents of the agreement are tru.ly unfair, then the standard agreement should be declared null and void, if the weak party feels compelled to accept the agreement, then it can be canceled.

The regulations governing the existence of financial institutions, including 
venture capital at this time are the Republic of Indonesia's Presidential Decree Number 61 of 1988 concerning Financing Institutions ${ }^{19}$ and Decree of the Minister of Finance of the Republic of Indonesia Number 1251 / KMK. 013/1988 concerning Provisions and Procedures for Implementing Financing Institutions. In order for the existence of venture capital to have a stronger and faster foundation in the community and to get support from various parties, it would be better if it is improved in the form of legislation.

\section{CONCLUSIONS AND SUGGESTIONS}

It is submitted that since Presidential Decree No. 9 in 2009 and the Decree of the Minister of Finance No. No. 18/PMK.010/2012 is silent on the rules of venture capital performance, the practice is based on the principle of freedom of contract, which implementation is under a contract (agreement) that submitted to the parties. The venture capital financing agreement is further implemented with a standard contract model, in which the format has been made in advance by a venture capital company, so often the partner companies only accept what is offered by venture capital companies, while the basic rules governing standard agreements in Indonesia not available. Such condition lead to the imbalanceness between the parties involved and ofthen considered as injustice. The partner company, whose position as a weak party, has not obtained legal protection properly.

It follows form the above that supervision and protection is necessary in order to maintain balancing interests and avoid bias. Such supervision and protection may come to the forms of basic legislation, appropriate control from the government, and by control conducted by judge (the court) and legal consultants and notaries. Thus, it is necessary to immediately determine the basic rules of standard contract, which formation is by considering the existing basic rules, namely: The provisions contained in article 18 of Law 8/19999 on Consumer Protection, Article 6.5.2. and 6.5.1.3. Burgelijke Wetboek in the new Netherlands, the basic rules laid down by the courts in England on the Raw Document Stipulation, and article 2302 Uniform Code 1978 in the United States.

\section{REFERENCES}

\section{Books}

Asikin, H. Z., Hukum Dagang, (Jakarta, Raja Grafindo Persada. 2013)

Asyhadie, Zaeni, Hukum Bisnis Prinsip dan Pelaksanaannya di Indonesia (Jakarta, PT Raja Grafindo Persada. 2012)

Brehny, Regina \& Brendan, Butler, A Guide to Ventura Capital, 8th Edition (Irish Venture Capital Association (IVCA), 2015)

Bungin, B. \& Widjajati, L., Dimensi Metodologis: Dalam Penelitian Sosial (Surabaya, Usaha Nasional, 2007)

Garner, B. A., Black's Law Dictionary. 8th Edition (West Publishing CO.St. Paul, Minn, 2004)

James, Kenneth \& Akrasanee, Narongchai, Small and Medium Business Improvement in the Asia. (Aspek-aspek Finansial Usaha Kecil dan Menengah: Studi Kasus Asean). penerjemah Yadrifil (Jakarta: LP3ES, 1992)

Rachmat, Budi, Modal Ventura: Cara Mudah Meningkatkan Usaha Mikro,

19 M. Isrok, 'Modal Ventura, Alternatif Baru untuk Pembiayaan Perusahaan' (1993) 1(1) Legality

Journal Ilmiah Hukum Malang, 11

102 | Sihabudin - Legal Protection for Investee Company in Venture Capital Agreement in Indonesia 
Kecil dan Menengah (Bogor, Ghalia Indonesia 2005)

Sukanto, Surjono, Penelitian Hukum Normatif (Jakarta, Adika Cipta, 1988)

Soekanto, Soejono dan Mamuji, Sri, Penelitian Hukum Normatif Suatu Tinjauan Singkat (Jakarta, Rajawali Pers, 2010)

Tambunan, Tulus, Usaha Mikro Kecil dan Menengah di Indonesia: Isu-isu Penting (Jakarta, LP3ES, 2012)

Zaman, B., dan Darus, M., Hukum Jaminan dan Jaminan Kredit Perbankan di Indonesia (Jakarta, Raja Grafindo Persada, 2007)

\section{Journal}

Asian Venture Capital Journal, The 1990

Guide to Venture Capital in Asia, Hong Kong: The Asian Venture Capital Journal Limited, 1990.

M. Isrok, 'Modal Ventura, Alternatif Baru untuk Pembiayaan Perusahaan' (1993) 1(1) Legality Journal Ilmiah Hukum Malang

Mack, Gradan, 'Fueling the Grouwth of Black Companies' (1994) 25(4) Journal Black Enterprise

\section{Legislations}

Article 1 paragraph (8) Draft Law on Small Business.

Article 26 paragraph (4) of Law No. 9 of 1995 concerning Small Business.

Act Number 20 Year 2008 concerning Micro, Small and Medium Enterprises. 